\title{
Portrait of the Writer as a Flâneur in Johannesburg? A Study of Ivan Vladislavić's Work
}

\section{Mathilde Rogez}

\section{(2) OpenEdition \\ 1 Journals}

Electronic version

URL: https://journals.openedition.org/ces/5127

DOI: $10.4000 /$ ces.5127

ISSN: 2534-6695

\section{Publisher}

SEPC (Société d'études des pays du Commonwealth)

\section{Printed version}

Date of publication: 1 September 2014

Number of pages: $57-66$

ISSN: 2270-0633

\section{Electronic reference}

Mathilde Rogez, "Portrait of the Writer as a Flâneur in Johannesburg? A Study of Ivan Vladislavić's Work", Commonwealth Essays and Studies [Online], 37.1 | 2014, Online since 14 April 2021, connection on 18 July 2021. URL: http://journals.openedition.org/ces/5127; DOI: https://doi.org/10.4000/ces. 5127

\section{(c) $(7)$}

Commonwealth Essays and Studies is licensed under a Licence Creative Commons Attribution - Pas d'Utilisation Commerciale - Pas de Modification 4.0 International. 


\section{Portrait of the Writer as a Flaneur in Johannesburg? A Study of Ivan Vladislavić's Work}

This article focusses on three of Ivan Vladislavić's novels as well as several essays and seeks to demonstrate that the navigations which they depict between the divided parts of Johannesburg, by car but also, interestingly, on foot, actually contribute to creating connections between them. The figure of the flaneur is replaced by that of the artist, in the kaleidoscopic vision that Vladislavić's writing offers of the South African metropolis.

Ivan Vladislavić's piece of "literary non-fiction" on Johannesburg, entitled Portrait with Keys, ${ }^{1}$ is one of the author's works which has attracted the greatest number of reviews and articles, if only because of the original attempt by its author to cross several areas of Johannesburg on foot: the streets of his neighbourhood, but also every single corridor and floor of its former major office and shopping complex, the Carlton Centre, and even some streets of the former CBD now abandoned by white people. Vladislavić seems to follow in the footsteps of many of his former characters, in particular Aubrey Tearle, the anti-hero of one of his previous novels, The Restless Supermarket. The latter culminated in an epic night stroll through Hillbrow which registered the irresistible change overcoming the city even before the official demise of apartheid. Vladislavić shifts to another mode of crossing the city in his latest novel, Double Negative, as the protagonist's favourite game is to try and recognise in which part of the city he finds himself while he sits with his eyes closed in his father's car moving through the South African metropolis. Despite this difference, this article would like to show that each of these various crossings through the city offers so many connections between its supposedly fragmented, segregated parts, through itineraries that criss-cross the city like so many patterns on a map. Vladislavić plays with various modes of moving through the city, as well as of writing on and about the city, encouraging his readers to navigate through each of his works as well as through his body of writing as a whole. We shall see besides that maybe because of Vladislavić's training in Fine Arts and his collaborations with architects and visual artists, readers are also invited to see some of his writing as a cross between literature and other modes of representation of and relation to the city.

Ivan Vladislavić was born in Pretoria in 1957 but considers himself a Johannesburger, since he has lived in Johannesburg since 1977, and is besides one of the South African writers, with Lionel Abrahams and Herman Charles Bosman, who has written the most extensively on that city. Quite a few of his short stories use the city as a background or an element of the plot, but the scope of this article cannot encompass them. In the rest of his work, be it fiction or non-fiction, Vladislavić has mostly written on Johannesburg as even more than just a setting, to the point that he has coined the phrase "Joburg books" (Dicey 39) to create a category in which to place Portrait with Keys, a book of "literary non-fiction" (Lenta 119), part journalism, part autobiography, which entirely takes place on the streets of Johannesburg which are looked at closely by

1. All references are to the American edition, which bears the subtitle The City of Johannesburg Unlocked, but the book was first published in South Africa in 2006 by Umuzi under the title Portrait with Keys: Johannesburg \& What-What. 
the narrator and the many characters he meets along the way. The Restless Supermarket, The Exploded View, and his most recent novel to date, Double Negative, also record the changes in the city and in the characters' perception of it. The Restless Supermarket, a novel in three chapters, registers the political changes as visible in the city's atmosphere and buildings, focussing on the neighbourhood of Hillbrow, as perceived by the fairly unpleasant Aubrey Tearle, a former proofreader of telephone directories obsessed with the English language. If the middle part of the novel is not pointedly on Johannesburg, it still focuses on a city, consisting of a fantasy or dream about a city falling apart, verging on organisational chaos, which a team of linguists manages to set right. The Exploded View is composed of four novellas, or is a novel in four interconnected parts which follow four characters in and around Johannesburg, as they criss-cross the city to check census forms with an array of respondents, or visit the building sites which are sprouting all over the city. As for Double Negative, it narrates the story of Neville Lister, a photographer specialized in photographing buildings, from youth through to middle age, and his life-changing meeting with the photographer Saul Auerbach, who teaches him to look at the city and its inhabitants in a totally different way. This article will also make use of a few other texts, essays and fiction, like "Modderfontein Road" or "The Real Monuments of Apartheid," which were published as parts of other works, for instance about artists like William Kentridge or Willem Boshoff, or about the building complex Sun City, as they also evoke the city of Johannesburg and shed light on Vladislavić's perspective on the city.

One feature that these works have in common is that they record the changes affecting the South African metropolis through time, around the fall of the apartheid regime, and in the first two decades of the new dispensation, the political changes being reflected in the city, its streets and buildings, and that those changes are perceived through a subject's, a character's reaction to the city. There is something surgical, technical to these works that provide "an exploded view" of the city, but also show a profoundly personal and sensitive view on it. Vladislavić is following in the footsteps of a Herman Charles Bosman or a Lionel Abrahams - literally, as these travels through the city are mainly carried out on foot, something fairly unusual for contemporary South Africa, the characters and narrators thus cutting a figure at times akin, at least at first sight, to that of the flaneur walking down the streets of Johannesburg. Those walks around the city paradoxically create as many links between its various parts, as well as echoes between Vladislavić's several works and the works he has done in collaboration with other artists.

\section{Crossing the City, Reaching out}

All of Vladislavić's works seem to be characterised by movement through a great many of the city's neighbourhoods, whose names are for instance reeled off in "A Farm in Eloff Street," the essay which accompanies William Kentridge's Tapestries. Means of transport figure prominently in at least his two latest novels, The Exploded View and Double Negative: in the former, the character of the first novella notices that he drives more than three hundred kilometres a day as he shuttles back and forth through the city to go and visit the respondents to a census who live in its various suburbs. In the latter Neville Lister drives from a squatter camp to the house of the wife of a former Minister, in quite a distant suburb. These patterns indicate that Vladislavićs novels present the act of crossing the city as creating a connection between its various parts and 
its different communities. In Double Negative, Neville Lister photographs with the same care a Congolese refugee barely making a living in a squatter camp, shyly standing in front of his makeshift house or a former model and wife of a minister posing outside her "African Imperial" style house, just as Saul Auerbach's pictures of a black mother of twins living in a dark shack and that of Mrs. Dillon, the fat white lady in her cosy house in Bezuidenhout Valley, are set up side by side on the wall of the exhibition room. The novel works on oppositions and contrasts, but also on similarities, as the phrasing of the passage on the shack and Mrs. Dillon's house suggests. The journalist who accompanies the photographer and Neville through the city sums up their day in a way which puts the two experiences, the two houses and their inhabitants, exactly on the same level: "That's two out of two" (68). The phrase, taken up by Neville, the narrator, suggests that both houses have stories to tell, even if their plots are not the same, their inhabitants' experiences differing so widely. The reason why this connection is achieved may be precisely because the characters do not just pick the two houses from afar, from their car, but go and knock on their doors, getting out of their car in the process. The character in the second part of The Exploded View may feel rather uncomfortable when getting out of his car, in the new housing complex building site his company is involved in, because that does indeed oblige him to have contact with other people. ${ }^{2}$ But getting in touch with his working partners is what is presented as the whole point of his drive, and the next moment, it is in the car itself that the protagonist comes into contact with some of the same people, as they are sitting in the minibus which is taking the whole company to the restaurant. A key example illustrating the purpose of this driving around would be the first part of the same novel, when the insistence is actually not that much on the journeys between the various places in the city, despite the sums that the driver is led to do of the distance between those locations represented by names on the motorways, but on their purpose, which is to meet the respondents, in particular the woman with whom the character becomes infatuated.

This idea seems emphasised in Vladislavićs Portrait with Keys, in which the way in which cars are referred to paradoxically suggests immobility rather than movement. Cars are presented not so much as means of moving around the city as an element actually preventing movement: when the narrator holds a party for his birthday, cars become a problem and need to be watched over. A guard is hired, but is regularly described not only as rooted to his post all night long, but also as creating a force of inertia, as the hosts similarly remain drawn to the spot where the cars are parked, rather than to the flow of the party. We could also mention the innumerable episodes involving the Gorilla, an anti-theft device which works so well that it always slows down the narrator when he wants to drive off, and even once jams, trapping the driver in his car just as a tramp is coming over to talk to him, putting him in an embarrassing situation. It is thus no wonder that he should be more inclined to walk, a preference that is stated almost from the beginning of the book and gives it its momentum, thanks to a turn of phrase which puns on the interplay of means of transport: "When I'm driven to walk, which is often" (section 5,21 ). The two modes are constantly associated in the book, for instance in the figure of the narrator's father, "a city man through and through, a lover of

2. It must be said that getting out of one's car becomes even more dangerous at the end of the last part of the novel, when the contact it leads to becomes that of the violent aggression of fists thudding on the body of the protagonist but that is because he has driven to a place where he should not be at the wrong time (201). 
walking and driving" (section 2,16), who uses maps of the city as a tool to make contact with lost drivers asking for directions, to get them out from behind the wheel. There even seems to be a gradation in the degree of importance granted to walking from one section to another of the text, as the narrator initially focuses on moments when he gets out of his car or happens to walk around his neighbourhood, to episodes when he deliberately organises "goodbye walks" or even walking tours with his friend or brother (section 8, 24, section 14, 33). The narrator even goes once to the infamous Hillbrow on foot, checking details for The Restless Supermarket (section 18, 38-39). The 138 sections or episodes that form the book look like so many steps on the way, in a city not meant for walking, several passages insisting on odd characters, "caged $\mathrm{m}[\mathrm{e}] \mathrm{n}$ " who walk madly in a circle $(37,144)$. The same idea can be found in Double Negative, in which a refugee is described as wearing shoes that do not look appropriate for walking in, now that he is in Johannesburg. In "Modderfontein Road" the only other people walking are workers, too poor to take a taxi, who look on, amused, as the narrator and his wife collect pine cones for their winter fire.

These humorous touches suggest that the walking figure in Vladislavić's work is no flaneur. What Michel de Certeau in The Practice of Everyday Life called "the long poem of walking" (101), as one idly perambulates through the streets, Baudelaire-like, is alluded to in section 34 (Portrait 53). But this is an attitude that Vladislavić knows is now associated with consumerism, with shopping malls, the only other place where one walks ironically, together with the poor neighbourhood of Hillbrow, as Marietta Kesting notes in her study of Sun City and building complexes in South Africa:

All the people hanging out on the sidewalks seemed like the spitting image of Benjamin's figure of the "flâneur" who loiters in public spaces. Yet - and maybe this is just a romanticized European projection - what is obvious is that Hillbrow is one of the few places where people walk on foot. The main other location in Johannesburg where this happens is the controlled environment of the shopping mall or the entertainment park. ("Dreams" 157)

Nor does Vladislavić adopt a detached perspective like that of the outsider or the foreigner evoked by Nat Nakasa, at the very beginning of his piece entitled "Johannesburg, Johannesburg":

People who have the best time in Johannesburg are the visitors. People who stay in town for a month or two and then fly out to their homes across the seas, with memories as their only link with Johannesburg. I've seen them sniff and stare at the city's narrow lanes where men smoke dagga. I've watched them enchanted by the opulence of the northern suburbs where whites live. These men, usually foreign correspondents from newspapers abroad, even find warmth in the squalor of the black slums. They look at Johannesburg from all angles, in much the same way as they would besiege a celebrated statesman at a press conference. They ask crucial questions without getting emotionally involved with the town's preoccupations. (3)

Vladislavić, contrary to these visitors, lives in Johannesburg. When he, or his narrator, goes away, at the end of the first half of Portrait with Keys, it is only temporarily and in order to better appreciate coming back in the second half, as if to his hometown, feeling the tug of home. The moment when the plane leaves ground, already, the narrator, "looking forward to seeing Joburg from the air" actually looked back at it, looking as well for the "intimate comfort in the vastness [...] that someone, inevitably, is looking back" (102-3). This exchange of looks points to the necessity for Vladislavić of remai- 
ning in touch with the city and its inhabitants - a necessity that appears all the more vital for him as a writer as these are his concluding words in Sun City:

$[Y]$ ou $[\ldots]$ have to be open, you have to remain curious about what is out there. You must want to engage, and it takes a bit of effort. [...] [F] or me personally it's imperative, if I am going to survive as a writer here and have some understanding of my society. I can't go and live in a gated community somewhere, it's too constrained and narrow. What version of my society would I have if I spent my days motoring between a gated community and a shopping mall? So I have to get out there and enjoy it - and watch my back at the same time. ("Real" 59)

What matters in fact is the perspective Vladislavić, or at least his alter ego in Portrait with Keys, adopts on the city and its inhabitants: the refusal of any overarching position. It may temporarily be that of the protagonist in the first part of The Exploded View, perched on a stool in a café overlooking the N1, and contemplating the flow of cars below him, but he is soon back in the thick of it. We can similarly draw a parallel between Portrait with Keys and Double Negative in order to understand the shift in perspectives constantly at play in Vladislavić's work. The young narrator of Portrait with Keys is gradually seized by a sort of dizziness as he climbs up the floors of the Carlton Centre and enjoys a breath-taking view on the city sprawling at his feet. But this is quickly followed by the conclusion that this only triggers once again a desire to go down and be part of it, at ground level:

Here, with the whole city for a backdrop, every white person capable of sitting up straight behind a desk appeared to be a business magnate. Up we went, floor by floor. The higher we toiled, the more spectacular the views became. On a clear day, it was said, you could see to Pretoria. I began to relish the moments when [...] I could stand before the window and look down at the immensity of the city, assured that even a hawker of telephone dixies could occupy the centre of it all. It was in those reflective moments that my sense of the unnatural beauty of Johannesburg was born and that I resolved to seek my fortune in these streets. (30, my italics)

Similarly in Double Negative, the photographer Saul Auerbach promptly refutes the notion that any such superior position would grant insight into the city:

"You think it would simplify things, looking down from up here," he went on, "but it has the opposite effect on me. If I try to imagine the lives going on in all these houses, the domestic dramas, the family sagas, it seems impossibly complicated. How could you ever do justice to something so rich in detail? You couldn't do it in a novel, let alone a photograph." (45, my emphasis)

The sentence structure and prepositions in the two passages are the same. It must be added that the three characters in Double Negative then leave the hill from which they were observing the city to find out what goes on in the houses they have selected, at street level this time, a little like Vlad in Portrait with Keys. Almost immediately after the passage previously quoted from the same work, though much later in terms of story time, it is from the level of the street, or even below, from that of the Carlton Centre underground car park whose levels have been closing one after the other, that the narrator appraises the shifts occurring throughout the city and the country: "[D]emand for parking fell, level by level, like a barometer of change in the city centre" (31). Literally as well as figuratively, the narrator has discarded any vantage point, and it is precisely this move and this new position, outside of his car, on foot and at street level, which allow him to reach out to other people, according to Jane Poyner: "By walking rather 
than driving through the streets of a city notorious for violent crime, Vlad symbolically divests himself of the privilege whiteness bestows and, in what amounts to a reconciliatory gesture, self-consciously inhabits the place of the other" (321). It is indeed while on his morning running session that a friend of the narrator's is able to meet properly a man he sees every day but never talks to, precisely because they are on another terrain, on foot and on the same footing:

As he's running along the Braamfontein Spruit early one morning, Mike sees a man lounging on a scrap of wasteland beneath a pylon, right beside the footpath. $[\ldots][\mathrm{H}] \mathrm{e}$ 's close enough to recognise the man: it's the gardener of the townhouse complex where he's staying $[\ldots]$. The man recognises him and calls a greeting. Mike stops to chat. Their paths have crossed half a dozen times in the past week around the complex, and Mike was struck by his submissiveness, but now he seems forthright and approachable. Meeting here on no-man's-land has freed them to stand in a different relation to one another, because Mike realises that he must also be a different person, here. (Portrait 158-9)

In another episode, it is when and because they get out of their respective cars to look at an upturned motorcycle by the side of the road that the narrator and another character realise that they are friends from long ago and start chatting. And we must keep in mind the long rambling walk through the CBD at dawn which closes The Restless Supermarket and allows the sour Aubrey Tearle to warm to the young Shirlaine who accompanies him, reaching across racial, gender and generational boundaries, and to truly capture the irretrievable change that has swept over the city: "It dawned on me that it really was over" (300). This sense of closure and loss cannot erase the moving and detailed episode which precedes this one, in which the two characters share more than simply food, the shabby street joint offering more warmth than the pseudo-friendly atmosphere the pretentious first floor of the Café Europa could ever provide.

\section{An Aesthetic of Fragments}

What this view at ground level provides the reader with is details, what Aubrey Tearle would no doubt call marginalia, or what Vladislavić calls the "[n]ondescript" in another essay:

Is there a more dismissive adjective? It suggests that a place cannot be evoked, that it has no qualities to distinguish it, that it is not worth remembering. But places are rendered vivid as much by what we bring to them as what we find there. "Nondescript" has this older, technical meaning: a species or specimen that has never been described before. ("Modderfontein" 159)

Just as Aubrey Tearle notices corrigenda in telephone books or press clippings, or new small shops in Hillbrow, the narrator of Portrait with Keys pays attention to the small details of the everyday: the number of beds being taken out during a removal, the shape of a loop of white paper lying on the ground, the few possessions of a tramp, the name of a car guard, a little plastic figure in the hole of a wall... As with the photographs of Mrs. Dillon and the shack-dweller, this raises the "non-descript" or the marginal to the same level as events of unquestioned importance - at least to that of the page. For the architect and academic Lindsay Bremner, this is in keeping with the nature of Johannesburg as a post-apartheid city:

The ordinary, everyday lives and practices of people $[\ldots]$ are $[\ldots]$ turning [the city] into an increasingly complex multiplicity of overlapping and intersecting social, cultural and 
economic transactions. It is in the tracing and mapping of these, in the narration of their intersections and the telling of their stories that new, provisional images of the future and its politics are emerging. (186)

Of course, this is also in keeping with what seems to be Vladislavić's most common mode of writing, which could be characterised as an aesthetic of fragments, if we think of his novels in short parts like The Exploded View, whose title speaks volumes, or of the 138 short sections that compose Portrait with Keys, another "exploded view" of sorts as Vladislavić explains in an interview (Dicey 44). Yet there is more to it than just fragments: whereas we might expect a mere index at the end of the book, what we find is a series of suggested "itineraries" which connect the sections and thanks to which readers might follow the narrator, or street names, or even people. Indeed, the "itineraries" section is not just full of place names, but also of those of people, embodying as it were the various faces of the city as an inhabited, lived-in place. What Vladislavić offers is a humanised vision of the city, the map of which he pictures from the beginning as a "fingerprint," the "skin of the earth" being lined uniquely with the presence of human beings (Portrait section 2,16). There are even some variants in the way the sections of a given itinerary are ordered in the previous publications in which they appeared separately, which again makes for a renewed, kaleidoscopic experience of reading, connecting elements in a rearranged form. It is the image of the mosaic, also present in one of the last sections of Portrait with Keys (section 132, 175), which comes to mind when Vladislavić describes his way of working, cutting and pasting fragments on a large sheet of paper and stepping back to observe the overall effect (Dicey 48). Those repetitive yet shifting views on a given point of the city besides offer a kind of cubist perspective on it, varying the angle each time and juxtaposing the new image to the previous picture obtained. Cubism and the coexisting multiple perspectives it offers are indeed evoked in the essay "Modderfontein Road" (156). In Portrait with Keys the various representations of the Ndebele mural on the wall of a house in the neighbourhood may also be viewed as cubist. Multiple points of view are given of its various stages: it is presented somewhat problematically in section 10 (26) and is ultimately painted over in section 40 (60-1), yet reappears in another section later on in the novel (section 66, 87-9). Never does it disappear completely from the physical world either, as it still shows through the paint after the first layer has been applied over it, and in the mind of the narrator years later when he speaks of it as a "pentimento," in which one can see the layers of paint "where the painter 'repented' or changed his mind" (89). And even if the narrator deplores not taking pictures or making notes of its progress, there is actually a written record of its existence, and even several, scattered throughout the book, coming back and showing through like the mural through the paint. As the painting becomes a form of palimpsest, the text takes up the form of a cubist mosaic which would at the same time borrow some of its features from the kaleidoscope.

The two images are used in Gerald Gaylard's chapter on Portrait with Keys in Marginal Spaces (295), but the latter is made to apply only to Italo Calvino's Invisible Cities. We would argue that the two, together with the notion of cubism, can apply to Vladislavićs work: thus in "Modderfontein Road" he goes back to the changes in the city and its suburbs, juxtaposing references to cubism and short paragraphs or fragments on apparently different topics on the same page, fragments printed in different colours on the page, and which nonetheless become linked in one thread of thought. The writer seems 
to work by association of ideas, which gives birth, as in a kaleidoscope, to new shapes. We thus find echoes between different parts within other works such as The Exploded View, and between several works, like the character of "S. Majara" who is to be found in both The Exploded View and Double Negative. It is probably no coincidence that the cover of the former should represent a bridge, that which connects initially separated places. In a way, Vladislavić's work is not so much about pulling things apart to expose them and understand how they work as, like the work of his artist S. Majara, putting them together again and making sense of them. Speaking about The Exploded View, Jan Steyn writes that

A case could be made that the novel's divided form is justified by its object: Johannesburg, which is, as cliché would have it, the "divided" city. But Vladislavić's tightly knit prose belies this diagnosis. Sensitive readers are struck by the uncanny repetitions, haunting resonances, and resounding echoes across the novel's parts: by the work's and the city's unity, not their partition. (n.p.)

\section{An Intermedial Work}

It is no wonder besides that one such key recurring figure, drawing a link between different pieces of Vladislavić's work, between various novels, should be that of the artist. Vladislavić himself has indeed worked with artists several times. He has published a number of essays in books focusing on other artists' works, like Willem Boshoff, William Kentridge, or more recently the photographer Mikhael Subotzky. More than that, quite a few of his novels are actually the result of such collaborations. The Exploded View thus stems from pieces of texts written to accompany an exhibition of drawings, The Model Men, by the artist Joachim Schönfeldt, to whom the published, full-length version of the novel is dedicated. Some of the first sections of Portrait with Keys, at least those which formed the three main itineraries, also came from collaborations with artists like David Goldblatt, and were only later expanded and put together as a volume standing on its own - through the cutting-and-pasting process, akin to the art of cubist mosaic mentioned above. Double Negative is another key example, as it is part of a joint project and publication again with the photographer David Goldblatt, on whom the character of Saul Auerbach in the novel seems modelled. We should hasten to add that the narrative does not simply duplicate the photographs reproduced in the companion collection of photographs, TJ. If one photograph could possibly match that of Mrs. Dillon, there is none of the woman in the shack with her twins. The narrative remains outside the frame of the photograph and focuses on what has not been captured on film. A similar process was at work in the volume edited by Terry Kurgan and Jo Ractliffe, Johannesburg Circa Now, in which Vladislavić took as a starting point a photograph, and from what was absent from it, wrote the short story "Helena Schein," which was to take on a life of its own in other collections of short stories, without the photograph to accompany it, under the title "The Book Lover." We see again here the link between the city of Johannesburg, its inhabitants and various artistic mediums, woven together by the flow of the narrative.

Actually, quite a few artists are mentioned in the "itineraries" or index at the end of Portrait with Keys. Most if not all go back to direct evocations in the body of the text of identifiable works of art by those artists, whose names and references are given in the notes that also figure at the end of the volume. One exception is the note to section 
127 which only identifies a quotation from William Kentridge. However, a close reading of the passage helps the reader reconstruct a landscape that could be akin to some of Kentridge's drawings:

Now you must go into the veld - don't forget your walking shoes - slowly, there's no rush. Crystals of black ash and charred stalks as brittle as the wing bones of birds shatter under your soles. Already assegais of new grass are thrusting through the scorched earth, prickling your eyes with their pointed green. The black crust crackles underfoot like remembered flames. 'Charcoal on the hoof.' What are you looking for? - a greasy bottle with a Smirnoff label. half a brick with a scab of cement and an iron rod twisting out of it. a flattened tin. the foundations of a ruined substation. three porcelain insulators thrown down from the pylons by the Escom electricians, as beautifully wrought as vases. a burnt out bulb. a signature. smudged lines. pencil stubs.

Are you still with me? In this dog-eared field, collapsing from one attitude to another, dragging your ghosts through the dirty air, your train of cast-off selves, constantly discovering yourself at the centre, in the present. (170)

The landscape is discovered by striking across the veld, on foot. The person addressed is invited to make a U-turn, to make his way back to the city, a move which is echoed by the alliterative pattern in the first sentences and the mirror-like structure of the sounds it creates, before those consonants break into a myriad shards like so many reflections, like so many "crystals," like the debris that are themselves scattered on the grass and listed in the text. A connection between them remains, however, as the sentences, although full-stopped, do not start with a capital letter. The ekphrasis becomes itself a mosaic, to be read at the right distance and angle, calling to mind yet another connection, this time with anamorphic drawings of the veld by the same Kentridge, in which one ultimately sees one's own reflection.

The act of reaching out to the other, achieved initially through crossing the city on foot, is thus also represented through the many shifts of perspective induced by Vladislavić's mode of writing. It creates and invites the reader to create connections between those various fragments, other texts, and other works of art. It is no wonder that Neville Lister, the protagonist of Double Negative, should take photographs of walls which gradually, as he comes to meet the people who inhabit the areas he crosses on foot, as their presence, however shy, starts to be felt on the premises, become "thresholds" (153). Lister, unlike Auerbach earlier in the story, no longer tries to trespass on their properties, but his may be another form of reaching over, a little like Vladislavić's: his text does not seek to intrude on Goldblatt's work, yet is not simply another negative either, a mere double which would cancel out the picture, but a cross, which readers need to learn to look at through shifting, anamorphic perspectives, so that the details of Johannesburg take shape to form an oblique "portrait" of the city.

Mathilde Rogez

University of Toulouse Jean-Jaurès

\section{Works Cited}

BREMNER, Lindsay. Writing the City into Being, Essays on Johannesburg 1998-2008. Johannesburg: Fourthwall, 2010.

Calvino, Italo. Invisible Cities. Trans. William Weaver. San Diego: Harcourt Brace \& C ${ }^{\circ}$, 1974. Trans. of Le città invisibili. Turin: Giulio Einaudi, 1972. 
De Certeau, Michel. The Practice of Everyday Life. Trans. Steven Rendall. Berkeley: U of California P, 1984. Trans. of L'Invention du quotidien. Paris: Gallimard, 1980.

DiCEy, William. "A Conversation with Ivan Vladislavić.” New Contrast 133. 34.3 (2006): 39-49.

GAYLARD, Gerald, ed. Marginal Spaces. Reading Ivan Vladislavić. Johannesburg: Wits UP, 2011.

—. "Migrant Ecology in the Postcolonial City in Portrait with Keys: Joburg \& What-What." In Gaylard 287-308.

Goldblatt, David, and Ivan Vladislavić. TJ - Johannesburg Photographs, 1948-2010/Double Negative, A Novel. Cape Town: Umuzi, 2010.

Kesting, Marietta, and Aljoscha Weskotrt, eds. Sun Tropes. Sun City and (Post-) Apartheid Culture in South Africa. Berlin: August Verlag, 2009.

Kesting, Marietta. "Dreams of Disco in Hillbrow: Entertainment in Johannesburg." Kesting and Weskott 141-61.

LENTA, Patrick. "Everyday Abnormality': Crime and In/security in Ivan Vladislavic's Portrait with Keys." The Journal of Commonwealth Literature 44.1 (2009): 117-33.

NakASA, Nat. "Johannesburg, Johannesburg." The World of Nat Nakasa. Ed. Essop Patel. 1975. Johannesburg: Picador Africa, 2005. 3-8.

Poyner, Jane. "Dismantling the Architecture of Apartheid: Vladislavićs Private Poetics in Portrait with Keys". Gaylard 309-26.

STEYN, Jan. "Unlearning the Art of Getting Lost: The Fiction of Ivan Vladislavić". The Quarterly Conversation (5 March 2012). <http://quarterlyconversation.com/unlearning-the-art-of-gettinglost-the-fiction-of-ivan-vladislavic > Consulted 10 July 2014.

Vladislavić, Ivan. The Restless Supermarket. Cape Town: David Philip, 2001.

-. The Exploded View. Johannesburg: Random, 2004.

-. "Helena Shein." Johannesburg Circa Now, Photography and the City. Ed. Terry Kurgan and Jo Ractliffe. Johannesburg: T. Kurgan and J. Ractliffe, 2005. 60-3.

-. Portrait with Keys: Johannesburg \&W What-What. Cape Town: Umuzi, 2006.

-. "A Farm in Eloff Street". William Kentridge Tapestries. Ed. Carlos Basualdo. New Haven; London: Yale UP and Philadelphia Museum of Art, 2008. 97-107.

—. "Modderfontein Road". Home Lands - Land Marks. Ed. Tamar Garb. London: Haunch of Venison, 2008. 154-61.

-. Portrait with Keys: The City of Johannesburg Unlocked. New York: W.W. Norton, 2009.

—. "The Real Monuments of Apartheid". Kesting and Weskott 39-59. 